Copyright (C) 2018 by Academic Publishing House Researcher

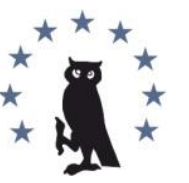

Published in the Russian Federation

European Researcher. Series A

Has been issued since 2010.

ISSN 2219-8229

E-ISSN 2224-0136

2018, 9(4): 279-283

DOI: $10.13187 /$ er.2018.4.279

www.erjournal.ru

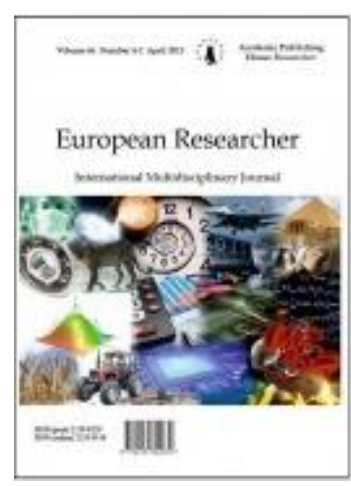

\title{
The Factors in the Occurrence and Development of Nomadism in the Territory of Central Kazakhstan
}

\author{
Bakhytgul K. Alzhapparova a, * \\ ${ }^{a}$ Eurasian National University named after L.N. Gumilyov, Republic of Kazakhstan
}

\begin{abstract}
This article attempts to trace the influence of the geographic factor in the emergence and formation of nomadic pastoralism in the territory of Central Kazakhstan. In this article the climatic and geographical conditions of the region are analyzed, the relationship between climate drought that occurred in the late Bronze Age and the emergence of a nomadic lifestyle is also traced. The author adheres to the thesis that nomadism was dictated by the struggle for survival, an attempt to find the optimal form of existence in the droughty conditions of the geographical area. The author examines the contemporary historiography of the question of the factors of nomadic pastoralism in the region, whose object of study became the pastoral household of the Kazakhs of Central Kazakhstan.
\end{abstract}

Keywords: nomadism, steppes, dispersion, region.

\section{Introduction}

The origins of nomadic pastoralism in Central Kazakhstan go back centuries, in the Bronze Age. This type of management can be called traditional, as for centuries, showing considerable stability and development, handed down from generation to generation, representing not just a life support system but the way of life of the Kazakhs. As Fernan Braudel pointed out, history is divided into three levels, the traditional household can be attributed to the sphere of "man, the earth, the space" - the very bottom, the deep layer of historical reality, dominated by the constancy and stable structures. "Time here runs so slowly that it seems motionless, changes of society's relationship and nature are measured by centuries and sometimes even in millennia" (Brodel Fernan, 1986: 19). It's almost motionless story of people in their close relationship with the land on which they walk, and that feeds them, history of constantly repeating dialogue with the nature ... (Brodel Fernan, 1986: 19).

Relevance of the research on this topic is also due to increased interest in regional issues. A regional approach to the study of such questions can successfully avoid such extremes as excessive generalization of the material schematically - stereotypical reflection of historical events. A region, as it is known, can have not only a geographical and economic, but also political, historical, cultural and even military nature. The focal area (Central Kazakhstan) takes a prominent position, has a unique historical tradition. In this region since ancient times there had been practiced the traditional Kazakh form of management - nomadic herding.

\footnotetext{
${ }^{*}$ Corresponding author

E-mail addresses: alzhapparova2015@mail.ru (B.K. Alzhapparova)
} 
On the role of geography in the history of civilization there were written by both domestic and foreign researchers. For example, Johnston R.J has written an essay about the history of Anglo-American social geography after 1945 (Dzhonston, 1987).

Considerable contribution to the coverage of this issue has made domestic scientist N.E. Masanov, who has studied the livelihoods of nomadic society of the Kazakhs. In his paper, the author focuses his attention on the relationship between environmental and socio-economic factors. The author characterizes the pastoral household of the Kazakhs as environmentally deterministic, multi-purpose and efficient, fully focused on the satisfaction of consumer interests of the local population. By revealing patterns of organization of the process of production, the author considers the special nature management mechanism - the variance (dispersion of ownership in the area) (Masanov, 1995).

The dispersity, by the author's opinion, was caused by a number of interrelated factors: droughty of areas, lack of food and water resources, the importance of soil conservation and ecological balance in natural and socio-economic processes. The author focuses on the environmental consequences of non-compliance of dispersion: pasture digression, desertification of areas and etc. It is dispersion, as says N.E. Masanov, led to community organizations and low population density (Masanov, 1995).

In this regard, it is of scientific interest the works of famous domestic scholar J.B. Abylhozhin (Abylkhozhin, 1989). In his studies, he holds an idea of forms depending on the household of the natural - climatic factors and adheres evidence-based point of view of most of the arid territory of Kazakhstan, which implies the development of cattle breeding, not cultivation. The author also considers the socio-economic aspects of the operation and transformation of traditional structures, characterizes the concept of "traditional ways", and examines the impact of reforms in the late 20ies XX century to strengthen the marginalization of the Kazakh village, explores the process of collectivization and its tragic outcome.

Great contribution to the study of this issue has made the work published in the form of essays, under the title "The traditional culture of Kazakhs life support." Authors of the collection reveal the various aspects and mechanisms for the implementation of the traditional culture of Kazakhs life support (TCKLS) such as nomadic herding, nomadic community, portable housing, and folk knowledge. Thus, N. Alimbay claims that TCKLS developed and functioned as an organic part of the economic and cultural activities. According to N. Alymbay, nomadic society's ultimate goal of production was not so much the production of wealth as community relations (Alimbay, Argynbayev, 1998).

However, it is necessary to establish the fact that the topic is poorly understood at the regional level (Central Kazakhstan), which implies the purpose and objectives of this study. In particular, it is not enough to study the effect of geographical factors on the formation of the nomadic pastoral household on the territory of Central Kazakhstan, insufficiently illuminated the historiography of this issue.

\section{Materials and methods}

Lighting of the traditional household of the Central Kazakhstan in the years of early twentieth century will not be, in our opinion, quite adequate and deep, if we do not direct our research interest in the natural and climatic characteristics of the region. The need to study the climatic conditions is due to the concept of geographical determinism, insisting on the existence of a direct link between the geographical features of the region and the specifics of the economic activity of people. After all, economic - cultural types depend, as is well known, on the specific geographical zones. As Grach D.A. wrote: "Because of this, for example, no one would ever think to look in the steppes of Mongolia hunters of sea mammals; equally it is impossible to search within the circumpolar zone, on the shores of the Arctic Ocean, people, herding sheep and camels" (Grach, 1984: 127).

A similar view was held by E. Huntington, arguing that climate, continuously pulsing, brings people to the prosperity, then decline. The decisive role in world events took place assigned to climatic factors: climate change could even lead to the death of a number of ancient civilizations of the East and led to the movement of nomads from Central Asia (Grach, 1984: 126).

In this article, we will adhere to the concept of geographical determinism, a theory which insists on the crucial role of the geographical factor in history. 


\section{Discussion}

Central Kazakhstan is far from the oceans and because of that continental climate therefore is expressed here stronger than in most other regions of Kazakhstan. This is noted by the researchers: "The climate of Central Kazakhstan includes the features of the climate of the northern deserts such as stretching through the territory of Eurasia from the lower reaches of the Volga River to the East China ranges" (Konobritskaya, 1954: 23). This climate is characterized by sharp temperature fluctuations during the day, summer heat, negative forty degree frosts in winter, dry air, low rainfall, and often blowing strong winds and snowstorms. Rainfall in Central Kazakhstan falls very little, and its number decreases rapidly in the direction from north to south. For example, in Karaganda, the average annual rainfall is $250 \mathrm{~mm}$, but in the Balkhash - only $100 \mathrm{~mm}$.

Agricultural scientists N.A. Tagil'tsev in his article quotes Nikolsky, which happened in 1885, a trip to Lake Balkhash: "Intolerable winds under clear skies, pillars of salt vortices scorching summer heat, lack of water and solitude, clay, round stunted bushes, larks, antelopes and lizards, phalanges, scorpions and mosquitoes ... only Central Asian nomads, adapted to this nature with their pastoral culture can only exist in the winter in these deserts "(Tagiltsev, 1928, 243).

In the desert Betpak - Dala annual precipitation ranges from 100 to $150 \mathrm{~mm}$, with one-third of their total number falls in early spring but in summer, during the growing season - only 15 percent (Masanov, 1995). The dry climate of Central Kazakhstan affected the river, most of them in the summer dries up or broken into stretches, and the water is strongly mineralized. Dry climate and aridity of the territory of Central Kazakhstan resulted in the predominance in the region of semi-desert and desert landscapes and their corresponding land cover. The north of Central Kazakhstan is represented with area grass steppes on dark chestnut soils, the middle part of Central Kazakhstan - a desert-steppe zone with a light-brown soils and sagebrush-saltwort vegetation and cereal.

The south of the region is dominated by saltwort desert with brown soils with patches of saline. For example, in the soil cover of the Karaganda region there is dominated by the complex semi-desert soils, and to the south - the typical desert gray soils. There is also disseminated soil as clay, sandy and gravelly solonetzic type with increased salinity in the lower parts of the terrain. This means that the soil of Karaganda region is unsuitable for large-scale agriculture, as well as the soil of the first two zones of the steppes of Central Kazakhstan (in varying degrees). The desert Betpak - Dala is also not suitable for agriculture, soil cover of which is represented by "thin solonized brown soils with patches of salt marshes, sand and dry-type playa" (Masanov, 1995). Under Betpak - Dala we must imply more or less homogeneous high plateau that lies in the watershed of the Chu River (downstream) and Sarysu and the western shore of Lake Balkhash. Among the plants it is dominated by those which better extract moisture from the deeper soil layers or easier to tolerate sudden temperature fluctuations. In the Kazakh farming of the Central Kazakhstan desert Betpak - Dala was widely used for grazing mostly fat-tailed sheep, the most adapted to long spans.

The soil cover of Balkhash region is dominated by gray-brown soils on compact rocks; plains develop grayish-brown soils with salt marshes and dry-type playa.

A more fertile are dark chestnut soils, prevalent mainly in the basin of the River Nury. In the arable layer they contain 3-4 \% humus, but among them there are sometimes found salt marshes, which lie on clays and loams. This area was good for autumn and spring, and in some places summer pastures for all kinds of cattle (Masanov, 1995: 172).

Thus, the natural and climatic conditions in Central Kazakhstan, established as far back as the Bronze Age: droughty climate, poor soil and water resources, the structure of economic activities caused the structure of the inhabitants of this region. About this wrote Kazakh agronomist P.G. Amosov, who has studied the geographical location and economic structure of the county Karkarala: "What a way other than grazing, people could use these spaces. There was no other way, they do not exist at present and they are unlikely to be available to our influence in the future?" (Amosov, 1926: 69).

Pastoral household of the Kazakhs, as has been said above, was formed in the era of antiquity. Researchers date the transition to nomadic transhumant 10-9 centuries. BC. (Begazy Dandybay stage) and therefore it is called Begazy - Dandybay culture - the culture of the nomadic tribes of the Andronov. 
On the broad development of cattle breeding in Central Kazakhstan region/Bronze Age/ there is archaeological evidence - material settlements and cemeteries. A particularly large number of domestic animal bones found by archaeologists during excavations of burial grounds of the Middle Bronze Age (Ayshrak, Aksu Ayuly, Bylkyldak, Temir-Astaz) and monuments of the Late Bronze Age (Begazy, Bugulov II, III, Sangru I, III, Kent ) and so on. Thus, nomadic herding was the predominant type of economic activity in Central Kazakhstan tribes already in the Bronze Age.

Regarding the factors that contributed to the emergence and development of nomadic pastoralism in the scientific literature, there are many points of view and hypotheses. According to one of them, the transition to nomadic pastoralism has been associated with an increase in livestock herds and the difficulty of their sustenance. Therefore, pastures changed periodically, and cattle graze farther and farther away from the settlements. Ultimately, the groups interested in cattle breeding stopped practicing agriculture and became nomads (Abylkhozhin, 1989). However, according to M.Hazanov, under extensive cattle breeding long and continuous growth of livestock numbers is not possible and therefore the desire to increase the number of livestock could not have been "motive of nomadization" (Khazanov, 2000: 178). According to Letimor, the emergence of nomadic pastoralism is explained by displacement of certain groups of people to the arid zones, due to the pressure of stronger neighbors, or as a result of overpopulation (Khazanov, 2000: 179).

In the scientific literature another point of view received approbation, which assumes existence of a link between climate change (gradual desiccation of the climate by the beginning of I millennium BC.) and the transition to a nomadic cattle breeding (Khazanov, 2000: 179). Because of this, we are of the opinion that the emergence and development of the nomadic pastoral household was due to the further adaptation of people to the harsh realities of the struggle for existence, trying to find a more rational and adequate to geographical conditions form of management. In this regard, it is quite legitimate statement by Arnold Toynbee, who asserted that nomadic civilization emerged as a result of a response to the challenge of the environment, and all efforts nomads directed at overcoming the challenges of Steppes. According to A. Toynbee, the nomads could not have beaten steppe and survived in such a harsh natural environment if they had not developed the intuition, self-control, physical and mental endurance (Toynbi, 1991: 183).

The special features of nomadic pastoralism, determining its economic essence, the researchers include the following features: 1) cattle as the predominant form of economic activity, 2) its extensive character associated with perennial stabling; 3) periodic mobility within certain grazing areas, or between them, caused by economic needs; 4) participation in the migrations of all or most of the population; 5) The natural character of the household. It is these economic needs of nomadic pastoralism which represent the basic and defining its specificity (Masanov, 1995: 84).

Archaeologically and historically data shows the forms of economic activity, developed in the Bronze Age, remained stable in the later stages of formation and development (up to the end of the 20-ies of XX century). Stability of economic forms, according to scientists, was determined by "uniformity of ecology" and "specificity of livestock farming", which was reflected in the fact that the "primitive accumulation of surplus product did not always have an upward trend, and social processes were often reversible."

The immediate impact on the system of material production and lifestyle of the Kazakhs was influenced by seasonal climate changes according to Alymbay Nursan, seasonally segmentation /жайлау, күзеу, қыстау, көктеу/ was "a particular way of socio-environmental and economic spatial organization of the territory" and a manifestation of the adaptive strategy of nomads " (Alimbay, Argynbayev, 1998: 49).

So, all kinds of nomadic grassland farms were needed for normal functioning. Thus, the traditional Kazakh household was so closely adapted to the landscape, which is almost a "top tier of biogeocoenosis" and after all these it was subject to all the nuances of seasonal and perennial natural rhythms.

\section{Conclusion}

Thus, nomadism as a lifestyle and as a type of household was dictated by the need to survive in the steppe and semi-desert areas of Central Kazakhstan. The geographical factor was decisive in 
the emergence of nomadic pastoralism. This type of household arose in the region in the late Bronze Age and passed a long way of development - until the 1920s.

It is also necessary to establish the fact that the traditional household of the Kazakhs of Central Kazakhstan, in particular, nomadic pastoralism, triggered a research interest in economists and agrarians in the 1920s. It must be emphasized that the majority of these researchers recognize the adaptive nature of the household of the Kazakhs, supported the view that the geographic conditions, poor soil and water are responsible for the household structure of the region.

\section{References}

Abylkhozhin, 1989 - Abylkhozhin, Zh.B. (1989). Traditsionnaya struktura Kazakhstana. Sotsialno-ekonomicheskiye aspekty funktsionirovaniya i transformatsii (1920-1930-e gg.). 240 p.

Alimbay, Argynbayev, 1998 - Alimbay, N., Argynbayev, Kh. (1998). Traditsionnaya kultura zhizneobespecheniya kazakhov. Ocherki teorii i istorii. Almaty: Gylym. 234 p.

Amosov, 1926 - Amosov, P.G. (1926). Khozyaystvenno-ekonomicheskiye nuzhdy i zadachi Karkaralinskogo uyezda // Narodnoye khozyaystvo Kazakhstana. №3. pp. 64-75.

Brodel Fernan, 1986 - Brodel, Fernan (1986). Struktury povsednevnosti: vozmozhnoye i nevozmozhnoye. M.: Progress. 1986. 610 p.

Grach, 1984 - Grach, A.D. (1984). Tsentralnaya Aziya - obshcheye i osobennoye v sochetanii sotsialnykh i geograficheskikh faktorov // Rol geograficheskogo faktora $\mathrm{v}$ istorii dokapitalisticheskikh obshchestv (po etnograficheskim dannym). L. Nauka. pp. 126-143.

Dzhonston, 1987 - Dzhonston, R.Dzh. (1987). Geografiya i geografy: ocherk razvitiya angloamerikanskoy sotsialnoy geografii posle 1945 goda. M.. Progress. 369 p. $603 \mathrm{p}$.

Khazanov, 2000 - Khazanov, M. (2000). Kochevniki i vneshniy mir. Almaty: Dayk-Press.

Konobritskaya, 1954 - Konobritskaya, G.M. (1954). Karagandinskaya oblast (ekonomiko geograficheskaya kharakteristika). Alma-Ata: Izd-vo AN Kaz. SSR. 256 p.

Masanov, 1995 - Masanov, N.E. (1995). Kochevaya tsivilizatsiya kazakhov (Osnovy zhiznedeyatelnosti nomadnogo obshchestva). Almaty «Sotsinvest». Moskva «Gorizont». 320 p.

Tagiltsev, 1991 - Tagiltsev, N. (1991). Ozero Balkhash i Pribalkhashskiy kray // Narodnoye khozyaystvo Kazakhstana. № 11-12. pp. 238-250.

Toynbi, 1991 - Toynbi Dzh. Arnold (1991). Postizheniye istorii. M.: Progress. 731 p.

Fenomen kochevnichestva v istorii Evrazii..., 2007 - Fenomen kochevnichestva v istorii Evrazii. Nomadizm i razvitiye gosudarstva. Almaty: Dayk-Press. 2007. 269 p. 